\title{
Hyperforin-Containing Extracts of St John's Wort Fail to Alter Gene Transcription in Brain Areas Involved in HPA Axis Control in a Long-Term Treatment Regimen in Rats
}

\author{
Veronika Butterweck ${ }^{1,2}$, Hilke Winterhoff ${ }^{2}$ and Miles Herkenham ${ }^{*, 1}$ \\ 'Section on Functional Neuroanatomy, NIMH, Bethesda, MD, USA; ${ }^{2}$ Institute of Pharmacology and Toxicology, Universitaetsklinikum Muenster, \\ Muenster, Germany
}

\begin{abstract}
We previously showed that a methanolic extract of St John's wort (SJW) (Hypericum) and hypericin, one of its active constituents, both have delayed regulation of genes that are involved in the control of the hypothalamic-pituitary-adrenal (HPA) axis. Hyperforin, another constituent of SJW, is active in vitro and has been proposed to be the active constituent for therapeutic efficacy in depression. We therefore examined if hyperforin has delayed effects on HPA axis control centers similar to those of Hypericum and hypericin. We used in situ hybridization histochemistry to examine in rats the effects of short-term (2 weeks) and long-term (8 weeks) oral administration of two hyperforin preparations, fluoxetine (positive control), and haloperidol (negative control) on the expression of genes involved in the regulation of the HPA axis. Fluoxetine $(10 \mathrm{mg} / \mathrm{kg}$ ) given daily for 8 weeks, but not 2 weeks, significantly decreased levels of corticotropinreleasing hormone $(\mathrm{CRH})$ mRNA by $22 \%$ in the paraventricular nucleus (PVN) of the hypothalamus and tyrosine hydroxylase (TH) mRNA by $23 \%$ in the locus coeruleus. Fluoxetine increased levels of mineralocorticoid (MR) (I7\%), glucocorticoid (GR) (I 8\%), and 5$H T_{\text {IA }}$ receptor (2I\%) mRNAs in the hippocampus at 8, but not 2, weeks. Comparable to haloperidol (I mg/kg), neither the hyperforinrich $\mathrm{CO}_{2}$ extract $(27 \mathrm{mg} / \mathrm{kg})$ nor hyperforin-trimethoxybenzoate $(8 \mathrm{mg} / \mathrm{kg})$ altered mRNA levels in brain structures relevant for HPA axis control at either time point. These data suggest that hyperforin and hyperforin derivatives are not involved in the regulation of genes that control HPA axis function.
\end{abstract}

Neuropsychopharmacology (2003) 28, 2 I60-2168, advance online publication, 16 July 2003; doi: I0.1038/s..npp. 1300253

Keywords: St John's wort; hypericum; hyperforin; fluoxetine; HPA axis; in situ hybridization

\section{INTRODUCTION}

Herbal extracts of Hypericum perforatum L. (St John's wort, SJW) are now successfully competing for status as a standard antidepressant therapy. Owing to this, great effort has been devoted to identifying the active antidepressant compounds. From a phytochemical point of view, SJW is one of the best-investigated medicinal plants. A series of bioactive compounds has been detected in the crude material, namely phenylpropanes, flavonol derivatives, biflavones, proanthocyanidines, xanthones, phloroglucinols, some amino acids, naphthodianthrones, and essential oil constituents (for a review, see Bombardelli and Morazzoni, 1995; Nahrstedt and Butterweck, 1997; Nahrstedt, 2000). Although SJW has been subjected to extensive scientific studies in the last decade, there are still many

*Correspondence: Dr M Herkenham, NIMH, NIH, DHHS, BIdg. 36, Rm. 2DI5, Bethesda, MD 20892-4070, USA, Tel: + I 30l 4968287 , Fax: + | 30I 402 2200, E-mail: milesh@codon.nih.gov

Received 05 February 2003; revised 02 May 2003; accepted 28 May 2003

Online publication: 30 May 2003 at http://www.acnp.org/citations/ Npp053003055/default.pdf open questions about the pharmacology and the mechanism of action. In fact, the active constituents are not fully known. The pharmacological activity of SJW extracts has recently been reviewed (Butterweck, 2003; Greeson et al, 2001; Nathan, 1999). Reports about the antidepressant activity of SJW extracts and their constituents both in vivo and in vitro have been published (Baureithel et al, 1997; Butterweck et al, 1997, 1998, 2000, 2001a, b, 2002; Calapai et al, 1999; Chatterjee et al, 1996, 1998a, b; Di Matteo et al, 2000; Franklin and Cowen, 2001; Gobbi et al, 1999, 2001; Müller et al, 1997, 1998, 2001; Simmen et al, 1999, 2001; Singer et al, 1999; Wonnemann et al, 2001).

A characteristic feature common to both tricyclic antidepressants and SJW is the delay of 10-14 days or more before the therapeutic effect becomes evident, and the efficacy continues to increase in the following weeks. The long delay may reflect long-term central nervous system biological adaptations occurring during the daily administrations. A common biological alteration in patients with major depression is the activation of the hypothalamicpituitary-adrenal (HPA) axis, manifested as hypersecretion of adrenocorticotropic hormone (ACTH) and cortisol and an abnormal cortisol response to dexamethasone and 
corticotropin-releasing hormone (CRH) administration (Gold et al, 1988; Holsboer and Barden, 1996; Holsboer et al, 1985; Raadsher et al, 1994). Correspondingly, the hyperactivity of the HPA axis in depressed patients was corrected during clinically effective therapy with antidepressant drugs (Barden et al, 1995; Holsboer et al, 1985).

In an animal study designed to examine the association between long-term antidepressant administration and the possibly delayed alteration in HPA axis activity, $\mathrm{CRH}$ mRNA levels in the hypothalamic paraventricular nucleus (PVN) of rats were shown to be decreased following longterm ( 8 weeks) but not short-term ( 2 weeks) treatment with imipramine, the prototypic tricyclic antidepressant (Brady et al, 1991). The same results were found with several other antidepressant drugs selected for their distinctly different primary pharmacological actions (Brady et al, 1992). Based on these data, we studied the effects of short-term (2 weeks) and long-term (8 weeks) administration of a methanolic SJW extract, hypericin and imipramine on the expression of genes that may be involved in the regulation of the HPA axis (Butterweck et al, 2001b). Our data showed that imipramine, SJW extract, and hypericin given daily for 8 weeks, but not for 2 weeks, significantly decreased levels of CRH mRNA in the PVN. Comparable to imipramine, the SJW extract and hypericin reduced plasma ACTH and corticosterone levels after 2 weeks of daily treatment. In line with previous findings (Brady et al, 1991; Nestler et al, 1990), we found that long-term treatment with imipramine significantly decreased TH mRNA levels in the locus coeruleus, whereas SJW extract and hypericin had no effect on $\mathrm{TH}$ message levels. Furthermore, long-term treatment with all three agents significantly decreased $5-\mathrm{HT}_{1 \mathrm{~A}}$ receptor mRNA expression in CA1 of the hippocampus. As the HPA axis effects could also be demonstrated with pure hypericin, it appears that the naphthodianthrone is a possible major active principle that may contribute to the beneficial effect of SJW extract after long-term oral dosing. The results obtained with hypericin could therefore be a starting point for approaches to design CNS-active molecules with a novel mode of action.

However, besides hypericin, pharmacological research on SJW has focused on either lipophilic extracts obtained with hypercritical $\mathrm{CO}_{2}$ that were devoid of hypericins and flavonoids, but enriched with hyperforin (Bhattacharya et al, 1998; Chatterjee et al, 1998b; Dimpfel et al, 1998; Franklin and Cowen, 2001; Gobbi et al, 2001; Simmen et al, 1999), or hydroalcoholic extracts that were standardized on a certain amount of hyperforin (Chatterjee et al, 1996, 1998b; Dimpfel et al, 1998; Franklin and Cowen, 2001; Gobbi et al, 2001; Simmen et al, 1999, 2001; Wonnemann et al, 2001). The phloroglucinol derivative hyperforin has recently become a molecule of increasing interest. Studies have demonstrated significant effects of hyperforin on various serotonergic, noradrenergic, dopaminergic, cholinergic, and opioid system activities in vitro (Chatterjee et al, 1998a; Holcomb et al, 1982; Müller et al, 1998, 2001; Neary et al, 2001; Simmen et al, 1999; Singer et al, 1999; Wonnemann et al, 2001). As the in vitro data have been used to argue that hyperforin is the major active principle of SJW extract, we determined in the present study whether it is active in vivo in a model of therapeutic efficacy. Thus, we gave daily oral administration of two preparations of hyperforin to rats in the short-term/long-term administration paradigm to determine if hyperforin had effects on the levels of the above-mentioned mRNAs in a manner similar to that of the methanolic SJW extract and hypericin. The effects were compared to those of the selective serotonin reuptake inhibitor (SSRI) fluoxetine. Fluoxetine was chosen as a reference control because it was shown in several studies that similar to the SSRI, hyperforin inhibited serotonin reuptake in in vitro experiments (Chatterjee et al, 1998a; Gobbi et al, 1999; Jensen et al, 2001; Müller et al, 1998; Neary et al, 2001; Simmen et al, 1999; Wonnemann et al, 2001).

\section{MATERIALS AND METHODS}

\section{Animals}

Male CD rats (150-180 g, Charles River WIGA, Sulzfeld, Germany) were single housed in a $12 \mathrm{~h}$ light/dark cycle, with lights off at 1900 , at a constant temperature of $25 \pm 1{ }^{\circ} \mathrm{C}$, and free access to food (Altromin 1324, Altromin Lage, Germany) and tap water. Rats were randomly assigned to the various experimental groups ( $n=8$ /group) and weighed daily. The experimental procedures used in this work were officially approved by the Regierungspräsident, Münster (A 92/99). Animals were killed between 0900 and 1100; the last drug administration was the day before between 1600 and 1700. Brains were removed, frozen by immersion in 2methyl butane at $-30^{\circ} \mathrm{C}$, and stored at $-70^{\circ} \mathrm{C}$ prior to sectioning. Trunk blood was collected on ice-chilled EDTAcoated $(10 \mathrm{ml})$ tubes containing $500 \mathrm{kIU}$ aprotinin $/ \mathrm{ml}$ and centrifuged. Plasma was frozen at $-70^{\circ} \mathrm{C}$.

\section{Chronic Antidepressant Treatment}

Fluoxetine hydrochloride was generously provided by Hexal (Holzkirchen, Germany), haloperidol-HCl was purchased from Sigma (Deisenhofen, Germany). A lipophilic SJW extract obtained with hypercritical $\mathrm{CO}_{2}$ (containing about $23.7 \%$ hyperforin and $6.2 \%$ adhyperforin) and hyperforintrimethoxybenzoate (TMB) were supplied by Indena S.p.A. (Milan, Italy).

All drugs were suspended in deionized water, and the solutions were emulsified with Tween-80 to a final concentration of $2 \%$ (Pälvimäki et al, 1994). Tween was also added to the deionized water received by the control groups (=vehicle). Fluoxetine $(10 \mathrm{mg} / \mathrm{kg})$, haloperidol ( $1 \mathrm{mg} / \mathrm{kg})$, hyperforin-TMB $(8 \mathrm{mg} / \mathrm{kg})$, and the $\mathrm{CO}_{2}$ extract $(27 \mathrm{mg} / \mathrm{kg})$ were dissolved with vehicle. Tween-80 was used as a solubilizer because the $\mathrm{CO}_{2}$ extract and hyperforinTMB are barely soluble in aqueous solutions. The final application volume of each preparation was $10 \mathrm{ml} / \mathrm{kg}$ body weight. Drug solutions were prepared fresh daily prior to use. In all experiments, substances were administered orally using the gavage technique. The oral administration route had to be chosen because (1) both the $\mathrm{CO}_{2}$ extract, and hyperforin-TMB are barely soluble in aqueous solvents and thus must be administered as an emulsion; (2) for chronic application, i.p. injections are contraindicated (Wolfensohn and Lloyd, 1994); and (3) gavage - if performed properly -is less stressful for animals than i.p. injection (Wolfensohn and Lloyd, 1994). For consistency of the 
method, fluoxetine and haloperidol were also given by gavage. Stock compounds were kept in light-tight containers at $-20^{\circ} \mathrm{C}$ under argon atmosphere. The $\mathrm{CO}_{2}$ extract $(27 \mathrm{mg} / \mathrm{kg})$ and the hyperforin-TMB $(8 \mathrm{mg} / \mathrm{kg})$ dosages were chosen because of their demonstrated efficacy in the forced swimming test. In preliminary experiments, the immobility times (seconds) at the optimized doses listed above were: control $(213 \pm 15)$; fluoxetine (94 $\pm 14, P<0.05$ vs control); $\mathrm{CO}_{2}$ extract (124 $\pm 11, P<0.05$ vs control); and hyperforin-TMB $(126 \pm 14, P<0.05 v s$ control). The application of hyperforin as an ester appeared to be necessary because hyperforin is extremely sensitive to light and oxidation processes and is decomposed in aqueous solutions. In pharmacokinetic studies, the release of hyperforin from the ester was demonstrated (P Morrazzoni, personal communication).

\section{Measurement of Corticosterone and ACTH}

Radioimmunoassay (RIA) of corticosterone was performed using $\left[{ }^{125} \mathrm{I}\right]$ corticosterone, antiserum, and standard solution in a kit from ICN Biomedical (Costa Mesa, CA, USA). The assay was adapted to rat serum conditions. Precipitation was performed using a second antibody solid phase. ACTH was measured using a kit from Diagnostic Systems Laboratories (Sinzheim, Germany). Both assays were performed according to the manufacturer's instructions. The inter- and intra-assay coefficients of variance for ACTH were 10.6 and $6.9 \%$, respectively, with a detection limit of $10 \mathrm{pg} / \mathrm{ml}$. For corticosterone, the inter- and intra-assay coefficients of variance were 7.2 and $4.4 \%$, with a detection limit of $15 \mathrm{ng} / \mathrm{ml}$.

\section{In Situ Hybridization Histochemistry}

Guided by Nissl-stained sections collected during the cutting and by the atlas of Paxinos and Watson (1998), coronal frozen sections ( $15 \mu \mathrm{m}$-thick) were collected at the levels of the midportion of the parvocellular region of the PVN where the magnocellular nucleus is largest $(-1.8 \mathrm{~mm})$; dorsal hippocampus $(-3.3 \mathrm{~mm})$, pituitary, and locus coeruleus $(-9.7 \mathrm{~mm})$. Sections were thaw-mounted onto gelatin-coated slides, dried, and stored at $-40^{\circ} \mathrm{C}$ prior to processing for in situ hybridization histochemistry.

The in situ hybridization histochemistry procedures were performed as described previously for ribonucleotide (cRNA) probes (Brady et al, 1991). First, tissue sections were processed by fixation with $4 \%$ formaldehyde solution, acetylation with $0.25 \%$ acetic anhydride in $0.1 \mathrm{M}$ triethanolamine- $\mathrm{HCl}, \mathrm{pH} 8.0$ solution, dehydration with ethanol, and delipidation with chloroform. Second, the antisense probes were transcribed from linearized plasmids using the Riboprobe System (Promega Biotech, Madison, WI) with ${ }^{35} \mathrm{~S}$-UTP (specific activity $>1000 \mathrm{Ci} / \mathrm{mmol}$; New England Nuclear, Boston, MA) and T7, T3, or SP6 RNA polymerase. The cDNA probes were: a $760 \mathrm{bp}$ fragment of rat CRH (a gift from Dr James Herman, University of Kentucky, Lexington, $\mathrm{KY}$ ), 923 bp of mouse pro-opiomelanocortin (POMC) (a gift from Dr James Douglass, Vollum Institute, Portland, OR), $384 \mathrm{bp}$ of rat tyrosine hydroxylase (TH) (a gift from Dr Barry Kosofsky, Harvard Medical School, Boston, MA), $900 \mathrm{bp}$ of the rat serotonin $5-\mathrm{HT}_{1 \mathrm{~A}}$ receptor gene (a gift from Dr Paul Albert, University of Ottawa, Ontario,
Canada), bases 81-528 of the rat glucocorticoid receptor (GR) (gifts from Dr Keith Yamamoto, University of California, San Francisco, CA), and 513 bases encoding the carboxy-terminal 25 amino acids of the rat mineralocorticoid receptor (MR) (gifts from Dr Jeffrey Arriza, Salk Institute, La Jolla, CA).

The radiolabeled probes were diluted in a riboprobe hybridization buffer and applied to brain sections (approximately $500000 \mathrm{cpm} /$ section). After overnight incubation at $55^{\circ} \mathrm{C}$ in a humidified chamber, slides containing brain sections were washed first in $20 \mu \mathrm{g} / \mathrm{ml}$ RNase solution and then $1 \mathrm{~h}$ each in $2 \times \mathrm{SSC}\left(50^{\circ} \mathrm{C}\right)$ and $0.2 \times \mathrm{SSC}\left(55\right.$ and $\left.60^{\circ} \mathrm{C}\right)$ solutions to reduce nonspecific binding of the probe. The slides were then dehydrated with ethanol and air-dried for autoradiography.

Slides and ${ }^{14} \mathrm{C}$ plastic standards containing known amounts of radioactivity (American Radiochemicals, St Louis, MO) were placed in X-ray cassettes, apposed to film (BioMax MR, Kodak, Rochester, NY) for periods ranging from 1 to $72 \mathrm{~h}$, and developed in an automatic processor (X-OMAT, Kodak).

\section{Data Analysis and Presentation}

Autoradiographic images were digitized with a solid-state camera (CCD-72, Dage-MTI) and a Macintosh computer using NIH Image software (Wayne Rasband, National Institute of Mental Health). Transmittance measurements were converted into $\mathrm{dpm} / \mathrm{mg}$ plastic using the calibration curve (Rodbard equation) generated from the standards. Brain structures were identified according to the atlas of Paxinos and Watson. Light transmittance through the film at PVN (CRH in the parvocellular division), hippocampus (5-HT $\left.\mathrm{HA}_{1 \mathrm{~A}}, \mathrm{MR}, \mathrm{GR}\right)$, anterior and intermediate lobes of pituitary (POMC), and locus coeruleus (TH) was measured by outlining the structure with the mouse cursor. The average value for each animal in experimental or control groups (based on four measurements per animal) was used to calculate group means ( $n=5-8$ per group). Except for the anterior pituitary, a density-slice function was applied to each structure; in the hippocampus, it was used to select and measure transmittance confined to the cellular layers of the CA fields and dentate gyrus. Mouse cursor control was used to outline the selected structure. The average value for each animal in experimental or control groups (based on four measurements per animal) was used to calculate group means ( $n=8$ per group).

One-way ANOVAs (drug treatment) were used to compare specific mRNA levels in control $v s$ treated groups. The Student-Newman-Keuls test was used for post hoc comparisons of mRNA levels in each hippocampal region. A criterion level of $P<0.05$ was used to determine significance.

\section{RESULTS}

Effects of Daily Antidepressant Treatment on CRH mRNA Levels in the PVN of the Hypothalamus and on POMC mRNA Levels in the Pituitary

CRH mRNA levels in the PVN were not significantly changed at 2 weeks (short-term administration), but were 
significantly decreased at 8 weeks (long-term administration) after treatment with fluoxetine (21\%) (Figure 1). No changes in mRNA expression of $\mathrm{CRH}$ in the PVN were observed for haloperidol, hyperforin-TMB, or the lipophilic $\mathrm{CO}_{2}$ extract at either time point. No treatment effects on the expression of POMC were observed in the anterior lobe of the pituitary (Table 1 ).

Effects on MR, GR, and 5-HT ${ }_{1 A}$ mRNA Levels in the Hippocampus

After 2 weeks of daily treatment, no significant changes in $\mathrm{MR}, \mathrm{GR}$, and $5-\mathrm{HT}_{1 \mathrm{~A}}$ receptor mRNA levels were found for any of the drugs (Table 1). Long-term treatment with fluoxetine significantly increased MR (18\%) and GR (19\%) receptor mRNA expression in the dentate gyrus of the hippocampus and $5-\mathrm{HT}_{1 \mathrm{~A}}$ receptor mRNA expression by 21

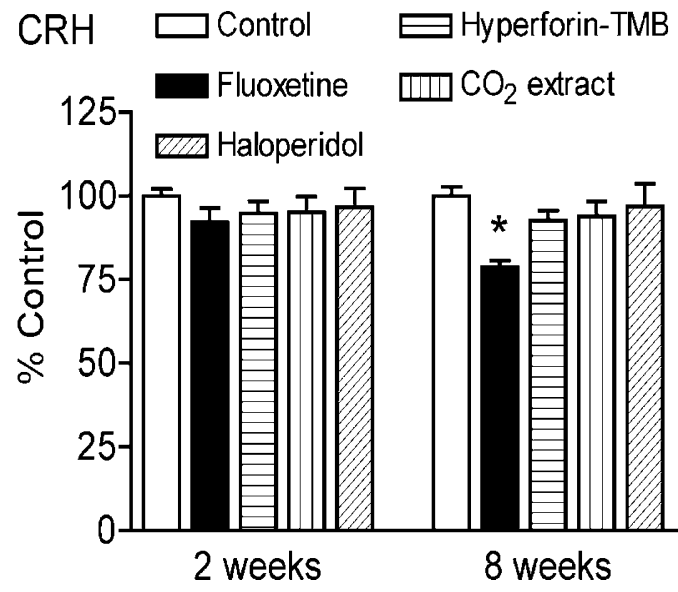

Figure I CRH mRNA expression in the PVN after 2 and 8 weeks of daily administration. and $22 \%$ in the hippocampal fields $\mathrm{CA} 1$ and $\mathrm{CA} 3$ relative to control (Table 1). No changes in mRNA expression of MR, $\mathrm{GR}$, and $5-\mathrm{HT}_{1 \mathrm{~A}}$ in the hippocampus were observed for haloperidol, hyperforin-TMB, or the lipophilic $\mathrm{CO}_{2}$ extract at either time point.

\section{Effects on TH mRNA Levels in the Locus Coeruleus}

No changes in TH mRNA levels were evident after 2 weeks for any treatment (Figure 2). After 8 weeks of daily fluoxetine administration, $\mathrm{TH}$ gene expression levels were decreased by $22 \%(P<0.05)$. Haloperidol, hyperforin-TMB, or the lipophilic $\mathrm{CO}_{2}$ extract did not alter TH mRNA levels.

\section{Effects on Hormone Levels, Body Weight, and Adrenal Gland Weight}

After 2 weeks of daily treatment, fluoxetine significantly increased plasma ACTH $(46 \%, P<0.001)$ and corticosterone $(417 \%, P<0.001)$ levels (Figure 3a,b). Haloperidol, hyperforin-TMB, or the lipophilic $\mathrm{CO}_{2}$ extract did not alter plasma hormone levels. No changes in hormone levels were observed after 8 weeks. Adrenal gland weights were not significantly altered by 2 or 8 weeks of chronic antidepressant treatment. Body weight was significantly decreased by fluoxetine $(\sim 10 \%, P<0.05)$ after 2 and 8 weeks and by haloperidol after 2 weeks $(13 \% P<0.05)$, but not after 8 weeks (Table 2).

\section{DISCUSSION}

Previous work validated the long-term drug administration protocol applied to unstressed eucortisolemic rats as an appropriate model for assessing the therapeutic efficacy of antidepressant drugs (Brady et al, 1991, 1992). The changes in mRNA expression levels of genes involved in the HPA axis control served to correct imbalances created in these

Table I Expression of mRNAs in Rat Brain after Short-Term and Long-Term Antidepressant Treatment

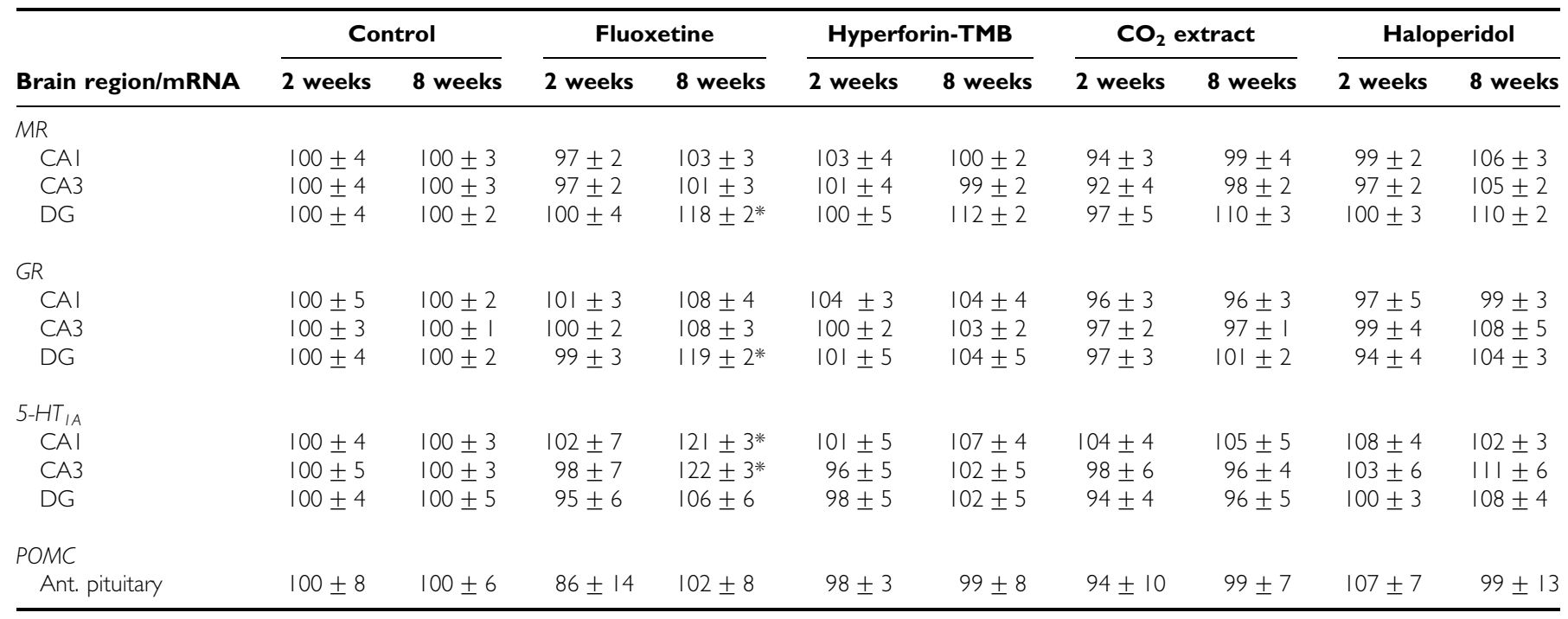

Values represent mean \pm SEM based on the average of four sections for each brain region per animal ( $n=8$ animals per group) and are expressed as percentage of the respective 2- or 8-week controls. Values significantly different from the respective 2- or 8-week control animals are expressed as $* P<0.05$ and $* * P<0.01$,

Student-Newman-Keuls post hoc test. 
neurochemical systems by chronic immobilization stress (Butterweck et al, 2001b). Brady et al (1991, 1992) showed that long-term treatment with imipramine, fluoxetine, idazoxan, and phenelzine reduces HPA axis activity and regulates gene transcription levels in relevant structures

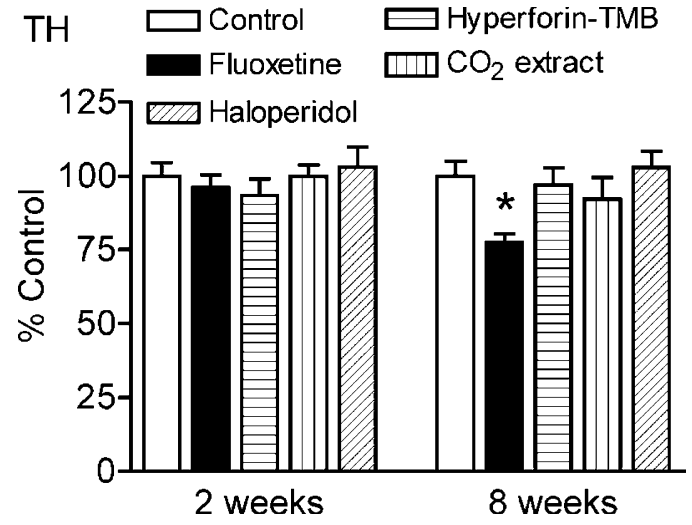

Figure $2 \mathrm{TH}$ mRNA expression in the locus coeruleus after 2 and 8 weeks of daily administration.

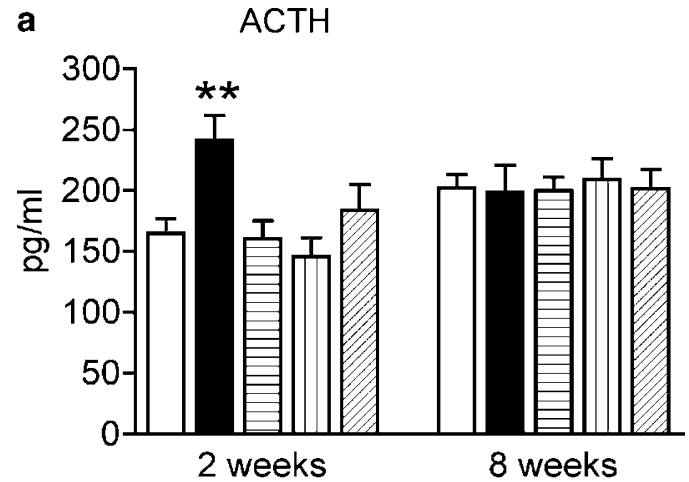

b Corticosterone

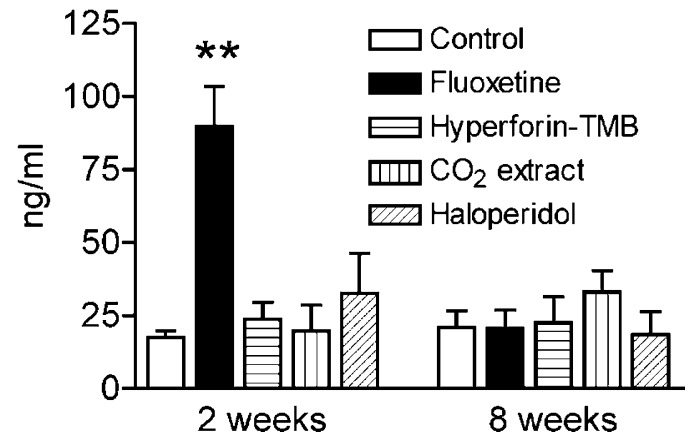

Figure 3 ACTH (a) and corticosterone (b) levels in plasma after 2 and 8 weeks of daily treatment. with delayed onset, resembling the delayed onset of therapeutic efficacy of these drugs when given to patients for treatment of depression. In the current study, using in situ hybridization histochemistry, we have examined the effect of chronic administration of the SSRI fluoxetine, the antipsychotic drug haloperidol, a lipophilic SJW extract prepared with supercritical $\mathrm{CO}_{2}$, and hyperforin-TMB on these same genes. Long-term ( 8 weeks), but not short-term ( 2 weeks), treatment with fluoxetine resulted in a marked decrease in CRH mRNA levels in the PVN and TH mRNA levels in the LC, and it produced an increase in hippocampal levels of $\mathrm{MR}, \mathrm{GR}$, and $5-\mathrm{HT}_{1 \mathrm{~A}} \mathrm{mRNA}$. In contrast, the negative control haloperidol $(1 \mathrm{mg} / \mathrm{kg})$, the hyperforin-rich $\mathrm{CO}_{2}$ extract $(27 \mathrm{mg} / \mathrm{kg})$, and hyperforinTMB $(8 \mathrm{mg} / \mathrm{kg})$ did not alter levels of gene transcription at either time point. These data suggest that hyperforin and hyperforin derivatives are not involved in the regulation of genes that control HPA axis function in a therapeutic administration paradigm.

We have previously reported that long-term administration of imipramine $(15 \mathrm{mg} / \mathrm{kg}$, p.o.), a methanolic SJW extract $(500 \mathrm{mg} / \mathrm{kg}$, p.o.), or hypericin $(0.2 \mathrm{mg} / \mathrm{kg}$, p.o.) all decreased CRH mRNA levels in the PVN (Butterweck et al, 2001b). The decrease in CRH mRNA levels in the PVN was accompanied by a decrease in POMC levels in the anterior lobe of the pituitary and in the plasma levels of ACTH and corticosterone. In light of the findings that CRH appears to be hypersecreted in depression, we suggested that the decrease in hypothalamic CRH expression induced by SJW extract and hypericin may be relevant to their therapeutic efficacy. The replication of the imipramine- (Brady et al, 1991) and fluoxetine-induced (Brady et al, 1992) delayed decreases in CRH mRNA levels in the PVN and the addition of significant data based on administration of plant substances (Butterweck et al, 2001b) further validate the short-term/long-term treatment paradigm for the assessment of efficacy of candidate antidepressant drugs. We hypothesize that if a downregulation of CRH mRNA in the PVN may be a common element relevant to the therapeutic efficacy of antidepressant drugs, the lack of effect of hyperforin and hyperforin derivatives on the regulation of HPA axis genes suggests that these substances are not necessarily involved in the beneficial effects of SJW after oral dosing.

In the present study, only fluoxetine altered mRNA levels of steroid hormone levels. In line with the finding of Brady et al (1992), the SSRI increased MR and GR mRNA levels in the hippocampus after 8 weeks, but not after 2 weeks, of drug treatment, indicating that differential regulatory mechanisms are operating to adjust limbic corticosteroid receptor number during antidepressant treatment. Similar antidepressant-induced increases of MR and GR mRNA expression have been reported in several in vitro and in vivo

Table 2 Adrenal and Body Weights in Short- and Long-term Administration Groups

\begin{tabular}{|c|c|c|c|c|c|c|c|c|c|c|}
\hline & \multicolumn{2}{|c|}{ Control } & \multicolumn{2}{|c|}{ Fluoxetine } & \multicolumn{2}{|c|}{ Hyperforin-TMB } & \multicolumn{2}{|c|}{$\mathrm{CO}_{2}$ extract } & \multicolumn{2}{|c|}{ Haloperidol } \\
\hline $\begin{array}{l}\text { Adrenal gland weight (mg) } \\
\text { Body weight }(\mathrm{g})\end{array}$ & $\begin{array}{r}56 \pm 3 \\
388 \pm 8\end{array}$ & $\begin{aligned} 57 & \pm 3 \\
429 & \pm 15\end{aligned}$ & $\begin{array}{c}50 \pm 2 \\
359 \pm 9 *\end{array}$ & $\begin{array}{c}53 \pm 3 \\
386 \pm 14 *\end{array}$ & $\begin{array}{c}53 \pm 2 \\
375 \pm 11\end{array}$ & $\begin{array}{c}52 \pm 3 \\
396 \pm 13\end{array}$ & $\begin{array}{c}59 \pm 2 \\
392 \pm 10\end{array}$ & $\begin{array}{c}56 \pm 3 \\
421 \pm 19\end{array}$ & $\begin{array}{c}58 \pm 3 \\
388 \pm 11\end{array}$ & $\begin{array}{c}56 \pm 3 \\
375 \pm 10 *\end{array}$ \\
\hline
\end{tabular}

Values are expressed as mean \pm SEM ( $n=8$ per group). Initial body weights were $160-180$ g. $* P<0.05$. 
studies (Budziszewska et al, 1994; Pepin et al, 1989; Pfeiffer et al, 1991; Reul et al, 1993; Seckl and Fink, 1992). It has also been shown that chronic administration of lithium, which is known to augment clinical effects of medication in depressed patients, as well as prolonged application of electroconvulsive shock (ECS), regarded as a nondrug therapy of depression, elevate GR mRNA levels or the density of GR and MR in the rat hippocampus (Pfeiffer et al, 1991; Przegalinski et al, 1993). GR and MR biosynthesis appears to be under control of central monoaminergic systems (Maccari et al, 1990, 1992; Mitchell et al, 1990; Weidenfeld and Feldmann, 1991). In vivo studies with monoamine-depleting agents (eg reserpine) and neurotoxic substances that specifically destroy serotonergic, noradrenergic, and/or dopaminergic nerve terminals have provided evidence for a modulatory role of monoamines in brain corticosteroid receptor regulation (Lowy, 1990; Seckl et al, 1990; Siegel et al, 1983; Weidenfeld et al, 1983). After chronic fluoxetine treatment, in vivo microdialysis studies have shown that extracellular levels of serotonin are markedly elevated (Rutter et al, 1994). Thus, in the present study, the increase in GR and MR mRNA levels after longterm fluoxetine treatment may be connected with the actions of the SSRI on serotonergic neurotransmission.

Apart from a role of the monoamines, fluoxetine-induced changes in plasma levels of ACTH and corticosterone may also be a factor contributing to the regulation of the corticosteroid receptors. Support for a stimulatory role of fluoxetine on the HPA axis has been provided by a number of studies. For instance, acute administration of fluoxetine to rats stimulates the secretion of pituitary ACTH and adrenal corticosterone in a dose-dependent manner (Dinan, 1996; Li et al, 1993a, b). In the present study, ACTH as well corticosterone levels were significantly increased after 2 weeks of daily fluoxetine treatment, and they were back to baseline levels after 8 weeks. This result is in contrast to other reports of decreased or baseline levels of ACTH and corticosterone plasma levels after repeated treatment of rats with fluoxetine (Brady et al, 1991, 1992; Lopez et al, 1998; Raap et al, 1999). One reason for these discrepancies might be the large variability in daily fluoxetine doses used in the different studies. Many studies using fluoxetine in rats have used doses of 10-30 mg/kg/day (Gardier et al, 1994; Nestler et al, 1990; Trouvin et al, 1993); others have used lower doses of 2.5-5 mg/kg/day (Brady et al, 1992; Nibuya et al, 1996). In these studies, the substance was given i.p. or subcutaneously, whereas in the present study, $10 \mathrm{mg} / \mathrm{kg}$ of fluoxetine was given orally by gavage. However, the antidepressant doses used in the present study were selected from the doses shown in animal models (forced swim test) to correlate with antidepressant activity.

In our study, POMC mRNA levels in the anterior pituitary were slightly reduced after 2 weeks of fluoxetine treatment, but this effect was not statistically significant. CRH mRNA levels were significantly decreased after 8 weeks of daily treatment with fluoxetine. These apparent discrepancies between increased plasma ACTH and corticosterone levels slightly reduced mRNA POMC levels after 2 weeks, and reduced $\mathrm{CRH}$ mRNA levels after 8 weeks of fluoxetine treatment might be explained by the fact that substances like fluoxetine, which increase central 5-HT concentration, may increase plasma ACTH and corticosterone levels through mechanisms that are independent from serotonergic innervation of CRH neurons in the PVN. In fact, it has been reported that 5-HT causes a direct ACTH secretion from anterior pituitary cells in vitro (Calogero et al, 1995). On the other hand, corticosteroids have been shown to alter several elements of serotonergic neurotransmission. The removal of circulating corticosteroids by adrenalectomy resulted in anatomically specific decreases in the indices of 5-HT metabolism (Chalmers et al, 1993; De Kloet et al, 1982; Zhong and Ciaranello, 1995). It is therefore likely that the increased ACTH and corticosterone levels observed in the present study after 2 weeks of fluoxetine treatment do not result from changes in HPA activity, but rather reflect a direct effect on pituitary cells caused by increased levels of serotonin.

As the hippocampus is also suggested to be a key component in the mediation of depression (Duman et al, 1997), the expression level of $5-\mathrm{HT}_{1 \mathrm{~A}}$ mRNA was measured in this structure. Several studies provide evidence that the activity and levels of $5-\mathrm{HT}_{1 \mathrm{~A}}$ receptors are modulated by glucocorticoid levels. It has been shown that removal of circulating corticosteroids acts to induce $5-\mathrm{HT}_{1 \mathrm{~A}}$ receptor expression. Autoradiographic studies first identified increased $5-\mathrm{HT}_{1 \mathrm{~A}}$ receptor binding in the rat hippocampus after adrenalectomy (Biegon et al, 1985). Subsequent investigations have confirmed the sensitivity of $5-\mathrm{HT}_{1 \mathrm{~A}}$ receptors to circulating corticosteroid levels (Chalmers et al, 1993, 1994; Zhong and Ciaranello, 1995). However, the fact that in the present study, plasma ACTH and corticosterone levels were found to be elevated after 2 weeks whereas hippocampal 5- $\mathrm{HT}_{1 \mathrm{~A}}$ mRNA was upregulated after 8 weeks indicates that differential or delayed regulatory mechanisms are operating to adjust limbic $5-\mathrm{HT}_{1 \mathrm{~A}}$ receptor number during fluoxetine treatment.

Long-term oral administration of fluoxetine was associated with a decrease in mRNA expression in the LC, whereas haloperidol $(1 \mathrm{mg} / \mathrm{kg})$, the $\mathrm{CO}_{2}$ extract $(27 \mathrm{mg} / \mathrm{kg})$, and hyperforin-TMB $(8 \mathrm{mg} / \mathrm{kg})$ had no effect on $\mathrm{TH}$ message levels. Data from previous studies suggest that the common action of antidepressants could be related to an effect on the regulation of $\mathrm{TH}$ in the $\mathrm{LC}$, but there is controversy in the literature in this regard. Whereas Brady et al (1992) report an upregulation of $\mathrm{TH}$ mRNA levels in the LC after 8 weeks of fluoxetine treatment $(5 \mathrm{mg} / \mathrm{kg}$, i.p.), Nestler et al (1990) found decreased levels of TH after 2 weeks of fluoxetine administration $(15 \mathrm{mg} / \mathrm{kg}$, i.p.). The apparent downregulation of $\mathrm{TH}$ by fluoxetine is particularly interesting and supports the view that the serotonergic system exerts an influence on the functional state of noradrenergic neurons (Valentino et al, 1990).

In summary, as a positive control, we replicated the effects of long-term fluoxetine administration on gene transcription in selected brain areas that are thought to be involved in HPA axis control (Brady et al, 1992). In contrast, a hyperforin-rich lipophilic $\mathrm{CO}_{2}$ extract as well as hyperforin-TMB failed to affect gene transcription associated with HPA axis control. Although some authors emphasize hyperforin as the major active principle of SJW, its efficacy could not be demonstrated in the present paradigm. In the present study, hyperforin was used as TMB, a hyperforin prodrug. The application of hyperforin as an ester appeared to be necessary because hyperforin is 
extremely sensitive to light and oxidation processes and is decomposed in aqueous solutions. In the present study, we tested the pharmacological activity of hyperforin-TMB, a new derivative synthesized with the aim of obtaining a more stable compound. Although hyperforin-TMB was inactive in the present study, it can be excluded that this effect is due to lack of its bioavailability. The release of hyperforin from the ester was demonstrated in pharmacokinetic studies. Furthermore, the dosage used in the present study proved to be active when tested in the forced swimming test (see Materials and methods). However, recently Cervo et al (2002) showed that hyperforin-used as a hyperforindicyclohexylammonium salt - was active in several behavioral models, but that the ester as well as the free drug could not be detected in the brain probably because of its poor passage through the blood-brain barrier. The authors speculate that the antidepressant-like effect of hyperforin might be mediated by a still unknown metabolite of this compound.

In our previous study, we showed that a methanolic SJW extract as well as hypericin reduced measures of HPA axis activity with delayed onset (after 8 weeks), indicating that the delayed changes may be important for their therapeutic efficacy. Based on our present study, we conclude that hyperforin and hyperforin derivatives might belong to the active compounds that contribute to the beneficial effects of SJW after oral dosing, but that these lipophilic compounds are not involved in the regulation of HPA axis control. However, other mechanisms relevant to antidepressant activity of these compounds are not excluded and need to be investigated in further in vivo studies.

\section{ACKNOWLEDGEMENTS}

We thank Dr P Morazzoni (Indena S.p.A., Milan, Italy) for the generous supply of the lipophilic $\mathrm{CO}_{2}$ extract and hyperforin-trimethoxybenzoate. We acknowledge the Hexal AG (Holzkirchen, Germany) for kindly providing fluoxetine-HCl. This work was supported by the NIMH Intramural Research Program.

\section{REFERENCES}

Barden N, Reul JM, Holsboer F (1995). Do antidepressants stabilize mood through actions on the hypothalamic-pituitary-adrenocortical system? Trends Neurosci 18: 6-11.

Baureithel KH, Buter KB, Engesser A, Burkard W, Schaffner W (1997). Inhibition of benzodiazepine binding in vitro by amentoflavone, a constituent of various species of Hypericum. Pharm Acta Helv 72: 153-157.

Bhattacharya SK, Chakrabarti A, Chatterjee SS (1998). Activity profiles of two hyperforin-containing Hypericum extracts in behavioral models. Pharmacopsychiatry 31: 22-29.

Biegon A, Rainbow TC, McEwen BS (1985). Corticosterone modulation of neurotransmitter receptors in rat hippocampus: a quantitative autoradiographic study. Brain Res 332: 309-314.

Bombardelli E, Morazzoni P (1995). Hypericum perforatum. Fitoterapia 66: 43-68.

Brady LS, Gold PW, Herkenham M, Lynn AB, Whitfield HJ (1992). The antidepressant fluoxetine, idazoxan and phenelzine alter corticotropin-releasing hormone and tyrosine hydroxylase mRNA levels in rat brain: therapeutic implications. Brain Res 572: 117-125.
Brady LS, Whitfield Jr H, Fox RJ, Gold PW, Herkenham M (1991). Long-term antidepressant administration alters corticotropinreleasing hormone, tyrosine hydroxylase, and mineralocorticoid receptor gene expression in rat brain. Therapeutic implications. J Clin Invest 87: 831-837.

Budziszewska B, Siwanowicz J, Przegalinski E (1994). The effect of chronic treatment with antidepressant drugs on the corticosteroid receptor levels in the rat hippocampus. Pol J Pharmacol 46: 147-152.

Butterweck V (2003). Mechanism of action of St John's wort in depression: what is known? CNS Drugs 17: 539-562.

Butterweck V, Jürgenliemk G, Nahrstedt A, Winterhoff $H$ (2000). Flavonoids from Hypericum perforatum show antidepressant activity in the forced swimming test. Planta Med 66: 3-6.

Butterweck V, Korte B, Winterhoff H (2001a). Pharmacological and endocrine effects of Hypericum perforatum and hypericin after repeated treatment. Pharmacospychiatry 34: S2-S7.

Butterweck V, Nahrstedt A, Evans J, Rauser L, Savage J, Popadak B et al (2002). In vitro receptor screening of pure constituents of St John's wort reveals novel interaction with a number of GPCR's. Psychopharmacology 162: 193-202.

Butterweck V, Petereit F, Winterhoff H, Nahrstedt A (1998). Solubilized hypericin and pseudohypericin from Hypericum perforatum exert antidepressant activity in the forced swimming test. Planta Med 64: 291-294.

Butterweck V, Wall A, Lieflander-Wulf U, Winterhoff $\mathrm{H}$, Nahrstedt A (1997). Effects of the total extract and fractions of Hypericum perforatum in animal assays for antidepressant activity. Pharmacopsychiatry 30: 117-124.

Butterweck V, Winterhoff H, Herkenham M (2001b). St John's wort, hypericin, and imipramine: a comparative analysis of mRNA levels in brain areas involved in HPA axis control following short-term and long-term administration in normal and stressed rats. Mol Psychiatry 6: 547-564.

Calapai G, Crupi A, Firenzuoli F, Costantino G, Inferrera G, Campo $\mathrm{G}$ et al (1999). Effects of Hypericum perforatum on levels of 5hydroxytryptamine, noradrenaline and dopamine in the cortex, diencephalon and brainstem of the rat. J Pharm Pharmacol 51: 723-728.

Calogero AE, Bagdy G, Burrello N, Polosa P, D’Agata R (1995). Role for serotonin 3 receptors in the control of adrenocorticotropic hormone release from rat pituitary cell cultures. Eur J Endocrinol 133: 251-254.

Cervo L, Rozio M, Ekalle-Soppe CB, Guiso G, Morazzoni P, Caccia $S$ (2002). Role of hyperforin in the antidepressant-like activity of Hypericum perforatum extracts. Psychopharmacology 164: 423428.

Chalmers DT, Kwak SP, Akil H, Watson SJ (1993). Corticosteroids regulate brain hippocampal $5-\mathrm{HT}_{1 \mathrm{~A}}$ receptor mRNA expression. J Neurosci 13: 914-923.

Chalmers DT, Lopez JF, Vazquez DM, Akil H, Watson SJ (1994). Regulation of hippocampal 5- $\mathrm{HT}_{1 \mathrm{~A}}$ receptor gene expression by dexamethasone. Neuropsychopharmacology 10: 215-222.

Chatterjee S, Bhattacharya S, Wonnemann M, Singer A, Mueller W (1998a). Hyperforin as a possible antidepressant component of hypericum extracts. Life Sci 63: 499-510.

Chatterjee SS, Koch E, Nöldner M, Biber A, Erdelmeier C (1996). Hyperforin and Hypericum extract: interaction with some neurotransmitter systems. Phytomedicine 3: 106.

Chatterjee SS, Nöldner M, Koch E, Erdelmeier C (1998b). Antidepressant activity of Hypericum perforatum and hyperforin: the neglected possibility. Pharmacopsychiatry 31: 7-15.

De Kloet ER, Kocvacs GL, Szabo G, Telegdy B, Bohus B, Versteeg DHG (1982). Decreased serotonin turnover in the dorsal hippocampus of rat brain shortly after adrenalectomy: selective normalization after corticosterone substitution. Brain Res 239 : 659-663. 
Di Matteo V, Di Giovanni G, Di Mascio M, Esposito E (2000). Effect of acute administration of Hypericum- $\mathrm{CO}_{2}$ extract on dopamine and serotonin release in the rat central nervous system. Pharmacopsychiatry 33: 14-18.

Dimpfel W, Schober F, Mannel M (1998). Effects of a methanolic extract and a hyperforin-enriched $\mathrm{CO} 2$ extract of St John's wort (Hypericum perforatum) on intracerebral field potentials in the freely moving rat (Tele-Stereo-EEG). Pharmacopsychiatry 31: 30-35.

Dinan TG (1996). Serotonin and the regulation of hypothalamicpituitary-adrenal axis function. Life Sci 58: 1683-1694.

Duman RS, Heninger GR, Nestler EJ (1997). A molecular and cellular theory of depression. Arch Gen Psychiatry 54: 597-606.

Franklin M, Cowen PJ (2001). Researching the antidepressant actions of Hypericum perforatum (St John's wort) in animals and man. Pharmacopsychiatry 34: S29-S37.

Gardier AM, Le Poul E, Trouvin JH, Chanut E, Dessalles MC, Jaquot C (1994). Changes in dopamine metabolism in rat forebrain regions after cessation of long-term fluoxetine treatment: relationship with brain concentrations of fluoxetine and norfluoxetine. Life Sci 54: PL51-PL56.

Gobbi M, Dalla Valle F, Ciapparelli C, Diomede L, Morazzoni L (1999). Hypericum perforatum L. extract does not inhibit 5-HT transporter in rat brain cortex. Naunyn-Schmiedeberg's Arch Pharmacol 360: 262-269.

Gobbi M, Moia M, Pirona L, Morazzoni P, Mennini T (2001). In vitro binding studies with two Hypericum perforatum extracts-hyperforin, hypericin and biapigenin-on 5- $\mathrm{HT}_{6}, 5-\mathrm{HT}_{7}$, $\mathrm{GABA}_{\mathrm{A}}$ /benzodiazepine, Sigma, NPY-Y1/Y2 receptors and dopamine transporters. Pharmacopsychiatry 34: S45-S48.

Gold P, Goodwin F, Chrousos G (1988). Clinical and biochemical manifestations of depression: relation to the neurobiology of stress. N Engl J Med 319: 348-353.

Greeson JM, Sanford B, Monti DA (2001). St John's wort (Hypericum perforatum): a review of the current pharmacological, toxicological, and clinical literature. Psychopharmacology 153: 402-414.

Holcomb HH, Bannon MJ, Roth RH (1982). Striatal dopamine autoreceptors uninfluenced by chronic administration of antidepressants. Eur J Pharmacol 82: 173-178.

Holsboer F, Barden N (1996). Antidepressants and hypothalamicpituitary-adrenocortical regulation. Endocr Rev 17: 187-205.

Holsboer F, Gerken A, Stalla G, Müller O (1985). ACTH, cortisol, and corticosterone output after ovine corticotropin-releasing factor challenge during depression and after recovery. Biol Psychiatry 20: 276-286.

Jensen AG, Hansen SH, Nielsen EO (2001). Adhyperforin as a contributor to the effect of Hypericum perforatum L. in biochemical models of antidepressant activity. Life Sci 68: 1593-1605.

Li Q, Brownfield MS, Battaglia G, Cabrera TM, Levy AD, Rittenhouse PA et al (1993a). Long-term treatment with the antidepressants fluoxetine and desipramine potentiates endocrine responses to the serotonin agonists 6-chloro-2-[1-piperazinyll-pyrazine (MK-212) and (+/-)-1-(2,5-dimethoxy-4iodophenyl)-2-aminopropane $\mathrm{HCl}$ (DOI). J Pharmacol Exp Ther 266: 836-844.

Li Q, Levy AD, Cabrera TM, Brownfield MS, Battaglia G, Van de Kar LD (1993b). Long-term fluoxetine, but not desipramine, inhibits the ACTH and oxytocin responses to the 5-HT agonist, 8-OH-DPAT in male rats. Brain Res 630: 148-156.

Lopez J, Chalmers D, Little K, Watson S (1998). Regulation of serotonin1A, glucocorticoid and mineralocorticoid receptor in rat brain and human hippocampus: implications for the neurobiology of depression. Biol Psychiatry 43: 547-573.

Lowy MT (1990). Reserpine-induced decrease in type I and II corticosteroid receptors in neuronal and lymphoid tissues of adrenalectomised rats. Neuroendocrinology 51: 190-196.
Maccari S, Le Moal M, Angelucci L, Mormede P (1990). Influence of 6-OHDA lesion of central noradrenergic systems on corticosteroid receptors and neuroendocrine responses to stress. Brain Res 533: 60-65.

Maccari S, Mormede P, Piazza PV, Simon H, Angelucci L, Le Moal M (1992). Hippocampal type I and type II corticosteroid receptors are modulated by central noradrenergic systems. Psychoneuroendocrinlogy 17: 103-112.

Mitchell JB, Rowe W, Boksa P, Meaney MJ (1990). Serotonin regulates type II corticosteroid receptor binding in hippocampal cell cultures. J Neurosci 10: 1745-1752.

Müller W, Rolli M, Schäfer C, Hafner U (1997). Effects of hypericum extract (LI 160) in biochemical models of antidepressant activity. Pharmacopsychiatry 30: 102-107.

Müller WE, Singer A, Wonnemann M (2001). Hyperforin-antidepressant activity by a novel mechanism of action. Pharmacopsychiatry 34: S98-S102.

Müller WE, Singer A, Wonnemann M, Hafner U, Rolli M, Schäfer C (1998). Hyperforin represents the neurotransmitter reuptake inhibiting constituent of hypericum extract. Pharmacopsychiatry 31: $16-21$.

Nahrstedt A (2000). Antidepressant constituents of Hypericum perforatum. In: Chrubasik S, Roufogalis BD (eds) Herbal Medicinal Products for the Treatment of Pain. Southern Cross University Press: Lismore. pp 144-153.

Nahrstedt A, Butterweck V (1997). Biologically active and other chemical constituents of the herb of Hypericum perforatum L. Pharmacopsychiatry 30: 129-134.

Nathan PJ (1999). The experimental and clinical pharmacology of St John's wort (Hypericum perforatum L.). Mol Psychiatry 4: 333-338.

Neary JT, Whittemore SR, Bu Y, Mehta H, Shi YF (2001). Biochemical mechanisms of action of Hypericum LI 160 in glial and neuronal cells: inhibition of neurotransmitter uptake and stimulation of extracellular signal regulated protein kinase. Pharmacopsychiatry 34: S103-S107.

Nestler EJ, McMahon A, Sabban EL, Tallman JF, Duman RS (1990). Chronic antidepressant administration decreases the expression of tyrosine hydroxylase in the rat locus coeruleus. Proc Natl Acad Sci USA 87: 7522-7526.

Nibuya M, Nestler E, Duman R (1996). Chronic antidepressant administration increases the expression of cAMP response element binding protein (CREB) in rat hippocampus. J Neurosci 16: 2365-2372.

Pälvimäki EP, Laakso A, Kuoppamäki M, Syvälahti E, Hietala J (1994). Up-regulation of $\beta_{1}$-adrenergic receptors in rat brain after chronic citalopram and fluoxetine treatments. Psychopharmacology 115: 543-546.

Paxinos G, Watson C (1998). The Rat Brain in Stereotaxic Coordinates. Academic Press: San Diego.

Pepin MC, Beaulieu S, Barden N (1989). Antidepressants regulate glucocorticoid receptor messenger RNA concentrations in primary neuronal cultures. Mol Brain Res 6: 77-83.

Pfeiffer A, Veilleux S, Barden N (1991). Antidepressants and other centrally acting drugs regulate glucocorticoid receptor messenger RNA levels in the rat brain. Psychoneuroendocrinlogy 16: 505-515.

Przegalinski E, Budziszewska B, Siwanowicz J, Jaworska L (1993). The effect of repeated combined treatment with nifedipine and antidepressant drugs on electroconvulsive shock on the hippocampal corticosteroid receptors in rats. Neuropharmacology 32: $1397-1400$.

Raadsher F, Hoogendijk W, Stam F, Tilders F, Swaab D (1994). Increased numbers of corticotropin-releasing hormone expressing neurons in the hypothalamic paraventricular nucleus of depressed patients. Neuroendocrinology 60: 436-444. 
Raap DK, Evans S, Garcia F, Li Q, Muma NA, Wolf WA et al (1999). Daily injections of fluoxetine induce dose-dependent desensitization of hypothalamic $5-\mathrm{HT}_{1 \mathrm{~A}}$ receptors: reductions in neuroendocrine responses to 8-OH-DPAT and in levels of $\mathrm{G}_{\mathrm{Z}}$ and $\mathrm{G}_{\mathrm{i}}$ proteins. J Pharmacol Exp Ther 288: 98-106.

Reul JMHM, Stec I, Söder M, Holsboer F (1993). Chronic treatment of rats with the antidepressant amitriptyline attenuates the activity of the hypothalamic-pituitary-adrenocortical system. Endocrinology 133: 312-320.

Rutter JJ, Gundlah C, Auerbach SB (1994). Increase in extracellular serotonin produced by uptake inhibitors is enhanced after chronic fluoxetine treatment. Neurosci Lett 171: 183-186.

Seckl JR, Dickson KL, Fink G (1990). Central 5,7-hydroxytryptamine lesions decrease hippocampal glucocorticoid and mineralocorticoid receptor messenger ribonucleic acid expression. $J$ Neuroendocrinol 2: 911-916.

Seckl JR, Fink G (1992). Antidepressants increase glucocorticoid and mineralocorticoid receptor mRNA expression in the rat hippocampus in vivo. Neuroendocrinology 55: 621-626.

Siegel RA, Weidenfeld J, Chen M, Feldmann S, Melamed E, Chowers I (1983). Hippocampal cell nuclear binding to corticosterone following 5,7-hydroxytryptamine. Mol Cell Endocrinol 31: 253-259.

Simmen U, Burkard W, Berger K, Schaffner W, Lundstrom K (1999). Extracts and constituents of Hypericum perforatum inhibit the binding of various ligands to recombinant receptors expressed with the Semliki Forest virus system. J Recept Signal Transduct Res 1 19: 59-74.
Simmen U, Higelin J, Berger-Büter K, Schaffner W, Lundstrom K (2001). Neurochemical studies with St John's wort in vitro. Pharmacopsychiatry 34: S137-S142.

Singer A, Wonnemann M, Müller W (1999). Hyperforin, a major antidepressant constituent of St John's Wort, inhibits serotonin uptake by elevating free intracellular $\mathrm{Na}^{+}$.J Pharmacol Exp Ther 290: 1363-1368.

Trouvin JH, Gardier AM, Chanut E, Pages N, Jaquot C (1993). Time course of brain serotonin metabolism after cessation of longterm fluoxetine treatment in the rat. Life Sci 52: PL187-PL192.

Valentino RJ, Curtis AL, Parris DG, Wehby RG (1990). Antidepressant actions on brain noradrenergic neurons. J Pharmacol Exp Ther 253: 833-840.

Weidenfeld J, Feldmann S (1991). Effect of 6-hydroxydopamine and 5,7-dihydroxytryptamine on tissue uptake and cell nuclear retention of corticosterone in the rat hypothalamus. Brain Res 566: 140-145.

Weidenfeld J, Siegel RA, Corcos AP, Chen M, Feldmann S, Chowers I (1983). Effect of 6-hydroxytryptamine on in vitro hippocampal corticosterone binding capacity in the male rat. Exp Brain Res 52: 121-124.

Wolfensohn S, Lloyd M (1994). Handbook of Laboratory Animal Management and Welfare. Oxford University Press: Oxford.

Wonnemann M, Singer A, Siebert B, Müller WE (2001). Evaluation of synaptosomal uptake inhibition of most relevant constituents of St John's wort. Pharmacopsychiatry 41: S148-S151.

Zhong P, Ciaranello RD (1995). Transcriptional regulation of hippocampal $5-\mathrm{HT}_{1 \mathrm{~A}}$ receptors by corticosteroid hormones. Brain Res Mol Brain Res 29: 23-34. 